\title{
Perspectives on Predator Management
}

\section{JOAN JOHNSON AND F. R. GARTNER}

Highlight: Too much adverse publicity has been given the sheep producer who struggles for existence in the face of rising costs, lower returns, and increasing numbers of predators. There seems to be adequate evidence that predator management is both necessary and practical on ranges used by either livestock or game. We cannot maintain the sheep industry in the United States without controlling predator populations. The lack of predator control in the past 2 years created economic crises in some sheep-producing areas of the West. Chemical control of coyotes under careful management and in selected areas appears to be biologically safe. At least this method should be utilized to reduce increasing coyote numbers until a perfected predator management system is devised. Man's influence on all ecosystems, whether private or public range, forest, shrub, or desert, nullifies the "balance of nature" concept. Our objectives in all areas of land management should be management oriented and designed for the uses desired, i.e., recreation, aesthetic value, wildlife, livestock, watershed, or a combination of these.

One of the topics least understood yet most bitterly condemned by a large segment of the general public is that of predator management. Recent predator policies have been influenced by emotion stemming from fears and sentimental desires of a few organizations and outspoken individuals who propose protectionist policies which unfairly favor predators. Public sentiment has been aroused to protect predators at any cost. Predator management is not popularly viewed as a game management tool, but rather as a mass extermination program initiated by and conducted for the sole benefit of special interest livestock groups. Public response has been highly emotional, and has blown the issue of predator management out of perspective.

Misconceptions about predators and their control are not new. Reporting on the biology of Harding County in northwestern South Dakota, Visher (1914) described the coyote as "abundant." Yet, in his assessment of the economic importance of the coyote he noted that "fences that are coyote proof are not difficult to make."

Leopold (1948), in Game Management stated: "Predatory animals affect four kinds of people: (1) agriculturists, (2) game managers and sportsmen, (3) students of natural history, (4) the fur industry. Each tends to assume that its interest is

The senior author is the wife of a Camp Crook, South Dakota, rancher, address: Camp Crook Route, Belle Fourche, S.D. The junior author is associate professor of animal science (range ecology), South Dakota State University, West River Agricultural Research and Extension Center, Rapid City. Approved by the director, South Dakota Agricultural Experiment Station as Journal Series No. 1317.

Paper was presented by Mrs. Johnson at the 26 th annual meeting,

Society for Range Management, February 9, 1973 , Boise, Idaho.

Manuscript received September 14, 1974. paramount." It is no wonder that the predator issue is controversial. In addition, there has been an abundance of biased rhetoric which, by virtue of its sensational nature, has received widespread public exposure in newspapers and popular magazines. Writing on the issue of predator control, Olson (1971) said: "The programs have already brought whole animal species to the edge of extinction, and they threaten still others." He ended his article with a prediction of a future day when "the last sickened coyote will lift his voice to the skies, and there will be no answer."

Statements alluding to the possible extinction of the coyote and most other predators are intended to capture the uninformed populace. Public lands occupy about one-third $(31 \%)$ of the total land area of the 17 Western states and nearly one-half $(48.5 \%)$ of the 11 Western states (Public Land Law Review Commission, 1970). The preservation of predator species is assured considering that national parks, monuments, and wildlife refuges, on which there is no predator control, occupy 17.5 million acres in the 17 Western states. Predator control will always be limited (if not prohibited) on other public lands in the West because of topographic limitations. Rampant predation on livestock (or game) ranges appears to be not only a waste of natural resources but unwise management and economically foolish when sufficient safeguards against possible extinction of coyotes are provided. Shelton (1973) observed that "coyotes are not an endangered species, and this concept should be removed from decision-making in predator management."

A favorite catch phrase of critics of animal control policies is "balance of nature." Many believe that if man would simply bow out, a balanced environment would exist. This sounds like a nice, simple solution, but like so many simple solutions it is unreal and idealistic. The term "balance" is in it self deceptive, implying stability. Animal populations were controlled the "natural" way by recurring cycles which decimated a species, the check being death by disease, famine, predation, and drastic climatic fluctuations. Scientists are aware of the need to manage animal populations and have the technology to do so. However, public sentiment has stifled application because of publicity given the "balance of nature" cause.

The Cain Committee was appointed in 1971 by Secretary of the Interior Rogers Morton to study the predator problem and make recommendations. Although a livestock representative was not included on the committee, Vivion (1972) quoted Morton as saying: "I absolutely guarantee that the findings of these experts will be given a full hearing and review by wool growers and cattlemen, as well as wildlife interests." However, the Cain Committee (1972) recommendations were released shortly before President Nixon's Executive Order No. 11643 of February 8, 1972, banning the use of chemical toxicants for controlling 
predatory mammals and birds. The promised hearing never materialized.

Many biologists have felt that the Executive Order far exceeded the Cain Committee recommendations. The Cain Committee recognized the need for relief from economic loss for stockmen and for the development of an effective nonlethal program before curtailing chemical toxicants. Adding to the confusion of the time, Wade (1974) noted the disparity between the two reports solicited by the federal government: the Cain Committee report favored steel traps over the use of chemical toxicants, while the Leopold Report (1964) concluded that the steel trap is one of the most damaging control methods. The Leopold Committee further stated that, when properly applied, 1080 meat baits were effective and humane in control of coyotes with very little damaging effect on other widlife. The Cain Committee report undoubtedly influenced the decision of the Environmental Protection Agency administrator William D. Ruckleshaus on March 10, 1972. His order suspended and cancelled the registration for use of strychnine, thallium sulphate, cyanide, and sodium monofluoroacetate (1080) in prairie and rangeland areas for the purpose of predator and rodent control.

Predator management is not popularly viewed as a game management tool, but rather as a mass extermination program initiated by and conducted for the sole benefit of special interest livestock groups. Public response has been highly emotional, and has blown the issue of predator management out of perspective.

The chemical compound 1080 was extensively researched by Atzert (1971) and is one of the most effective predator control tools available. He reported that it is bio-degradable in soil, highly soluble in water, and unstable above $110^{\circ} \mathrm{C}$. Lethal dosages differ for different animal species, and selectivity is possible by varying the concentration of sodium monofluoroacetate in the bait material. Secondary poisoning was rare and tertiary poisoning unheard of. The use of sodium monofluoroacetate by the Bureau of Sport Fisheries and Wildlife resulted in but 37 known incidents of domestic animal poisoning from 1959 to 1969 , according to Atzert. No human fatalities have ever resulted from bureau use to control coyote and field rodent damage (Atzert, 1971).

To increase effectiveness for target predators, 1080 baits were placed as late in the fall as practicable by federal personnel and removed as early in the spring as weather permitted. Placement was along established crossings and driftways used by the target species. Baits were securely fastened to immovable objects and the location described in writing to assure recovery and maximum protection for nontarget species. At least two persons were to have first-hand knowledge of each location, and written permission of landowners was secured. Baits were disposed of by burning and burying or by deep burial. Area residents were to be notified and appropriate warning signs posted on roads and trails leading to the site, at the site, and at other locations deemed necessary.

Only $10 \%$ of the 1080 manufactured in the United States was used for predator control. The balance is still in use today for urban rat control and for export, according to Vivion (1972). Unfortunately, this compound has been lumped into the same category as the highly toxic and residually dangerous thallium sulphate, which, because of its undesirable qualities, was discontinued as part of the federal program. The U.S. Department of the Interior Draft Environmental Statement on

\section{H. R. 13152 stated:}

Since poisons will be prohibited from field use for killing predatory animals on Federal lands, 80 percent of the predatory animals now being killed annually may live to play active roles in range land ecosystems and other habitats which they occupy.

(U.S. Dep. of the Interior, 1972.)

"Predators by definition are carnivores: they eat meat," stated the Cain Committee (1972). A popular myth is that predators kill only sick, aged, or weakened animals. Shelton (1973) conceded that this may be true when applicd to big game species, but not so of domestic animals. The opposite is generally true. Shelton repeatedly tested this fallacy by exposing sich or injured animals to coyotes, but with practically no success. The Cain Committee (1972) noted: "As a matter of averages, the flesh-eaters feed upon what is most easily availablc...vulnerability has been greatly oversimplified in the public mind. .

Sheep are notoriously defenseless domestic animals, especially at lambing time, and therefore constitute prime targets for predators. The defensive reactions of sheepmen to the removal of the only effective method of protecting their flocks from excessive losses is understandable, but only serves to widen the communication gap. The problem is compounded by the lack of an understanding press and a shortage of statistical evidence. Busner (1972), in an open letter to Wyoming sheepmen, challenged the industry to produce research concerning (a) verified sheep and lamb losses due to predators to determine actual loss ratios, (b) population dynamics and movement of predators, (c) behavioral characteristics of predators (why some are livestock killers and others in the same area are not), (d) the positive value of predators in both natural and managed ecosystems, and (e) the development of nonlethal agents for the protection of livestock. Although a few states have obtained factual loss data, the figures may not apply on a regional scale. Information on livestock losses is primarily based on estimates, since absolute proof is difficult or sometimes impossible to obtain. The individual rancher generally can assess his own losses with a fair amount of accuracy, but predation is often a local problem, varying in degree with environmental factors, kinds and densities of predators, and local livestock management practices.

To fill the breach in factual information, research has been initiated using radio telemetry and experienced fieldmen and veterinarians to verify causes of death. Some data have recently been made available. Coyotes killed nearly 240 lambs on one ranch in Montana between about April 1 and June 30, 1974. These figures were gathered by two full-time observers of the U.S. Department of the Interior assigned to study no-control coyote kills. They made daily checks to determine death causes which were estimated to be $87 \%$ attributable to coyotes in 1974 (Lorang, 1974b). At the University of Nebraska Meat Research Unit, losses of mature sheep were 9\% in 1973, and lambs had to be totally confined to avoid losses (Lorang, 1974a).

Utah researchers noted that the magnitude of predator losses to individual owners is not adequately reflected when one merely views the total lamb crop and computes average 
loss figures (Davenport et al., 1973). They stated:

When evaluating such losses a sheepman may view his loss much as the average citizen would if he personally had to extract $\$ 25.00$ (approximate market value of a $90 \mathrm{lb}$ lamb at $28 \phi$ per pound in 1972) from his purse each time a coyote killed a lamb. In this light, 102 lambs, 46 lambs, or even two lambs can be highly significant.

Their data from 10 sheep herds in Utah indicated that the percentage of total lamb deaths verified as predator caused was 16.3\%. However, when examined on a herd basis, verified losses of $2,15,29,46$, and 102 lambs to coyotes converted to $1.8,22.7,40.3,18.4$, and $22.2 \%$, respectively, of the total lambs lost by each operator. Davenport et al. (1973) concluded: "The reason for the sheepman's concern about the percent of the total loss attributable to coyote predation is simply that he has little control over this loss whereas he can influence the magnitude of other losses through improved management."

Studies are also currently under way to develop more selective control methods. Prior to the 1972 action, President Nixon had frozen funds appropriated by Congress for this purpose, greatly retarding needed research. Many people may be surprised to learn that the National Wool Growers Association was the only group advocating such research at that time (Vivion, 1972).

Pfohman (1970), stated in the Baker, Oregon, Democrat-Herald that "the range sheep business in the West is edging each day closer to extinction. The increasing financial squeeze between operating costs and income has affected operators throughout the Nation ...Lamb and wool prices have not increased in proportion to other commodities. Predators have wreaked havoc in the herds. Cougars, coyotes and golden eagles have all taken their deadly toll among the young lambs." Sheep farmers and ranchers are saddled with a 17 million dollar per year loss from predators in the principal sheep growing states, and cannot survive the projected $80 \%$ increase in predatory animals (Vivion, 1972). A study of sheep production on the Northern Great Plains by Woolfolk (1949) specifically mentioned predator damage as well as direct losses. Death losses in the experimental flock were high each year and additional unmeasured losses occurred in the form of reduced weight gains due to disrupted activities. Preservationists quick to claim ownership of predators and demand their exemption from control programs are not so quick to assume financial responsibility for their actions. Losses are presently being absorbed by stockmen. With the spiralling cost of red meat, predators represent another threat to our economic structure by competing with consumers for this vital commodity.

The 1972 lamb crop was down 11\%, shorn wool production decreased, and total sheep inventory was down $6 \%$ in the 11 Western states (U.S. Dep. Agr., 1972). In the 17 Western states the 1973 lamb crop was $8.7 \%$ below that of 1972 , and ewe numbers on January 1,1974 , were $6.8 \%$ below those of a year earlier (Extension Service, 1973 \& 1974). National spokesmen for the sheep industry name predation as the number one threat to the future of the industry if present policies are continued.

Wildlife interests argue that rodent populations would explode and cause severe damage to ranges if coyote numbers were reduced. The Cain Committee (1972), comprised of wildlife scientists, noted that in many grazing ranges of the
West, existing populations of coyotes and other predators do not control rodents and lagomorphs to what might be considered "economic" levels.

A popular myth is that predators kill only sick, aged, or weakened animals. Shelton (1973) conceded that this may be true when applied to big game species, but not so of domestic animals. The opposite is generally true. Shelton (1973) repeatedly tested this fallacy by exposing sick or injured animals to coyotes, but with practically no success.

Udy (1953) in Utah, and Arrington and Edwards (1951) in Arizona, reported that antelope kid survival rates were significantly higher in areas of coyote control compared to areas of no control. The phenomenal increase of antelope in the Trans-Pecos area of Texas since the 1920's has been attributed to improved predator control methods. Interactions of pronghorns with coyotes and golden eagles were observed by Bruns (1970), who concluded that coyotes do not appear to prey selectively on wounded or aged animals. A golden eagle was observed killing a pronghorn having an estimated live weight of 70 pounds. Coyote and bobcat control on the vast King Ranch was reorganized and intensified in 1946 in coopcration with the Bureau of Sport Fisherics and Wildlife. For a period of 15 years, for which records are available, the King Ranch had deer, turkey, and javelina populations consistently higher than any other known area with comparable environmental conditions (Cadieux, 1960).

Cook et al. (1971) reported a $72 \%$ mortality rate for deer fawns, and major causes of death were: predation (53\%)-mostly by coyotes, and starvation and/or disease (16\%). Bright (1971), citing a 1969 inventory of the Northwest Interstate mule deer ranges, noted that summer fawn survival was from 8 to $45 \%$ higher in areas where predators were controlled. Bright also noted that other researchers have observed that concentrations of predators attracted and maintained by an abundance of livestock will cause unusual damage to game when stock is seasonally shipped out to feed yards or other ranges.

Average annual pheasant brood production was $45 \%$ higher on the predator reduction area than the area of no control in a South Dakota study (Carter and Trautman, 1969). Gabrielson (1941) concluded that the utilization of the game crop by man may necessitate some reduction in numbers of predatory species if a supply of game is to be maintained. Presnall (1950) emphasized that there is need to avoid confusion caused by attempted application of wilderness philosophies to developed areas. He further stated: "Predator control on the basis of facts rather than fancies has its proper place among the tools of environmental management."

The Bureau of Sport Fisheries and Wildlife coyote control program has not held down populations of nontarget predators; in fact, the population levels of most nontarget predators have increased in areas where the Bureau has conducted coyote control for 20 years (Robinson, 1961).

Managers of both public and private lands are today faced with decisions involving the proper "balance" of both plant and animal species. On some ranges woody plants have increased at the expense of herbaceous vegetation. Elsewhere one animal species has increased to the detriment of another species with limited productivity of the range for both. Managerial decisions should be based on biological 
considerations, especially on public lands. Too often, however, critical decisions are made after political pressure has been injected in the process from the "top downward" as a result of emotional influence by numerically important preservationist groups.

\begin{abstract}
Preservationists quick to claim ownership of predators and demand their exemption from control programs are not so quick to assume financial responsibility for their actions. Losses are presently being absorbed by stockmen. With the spiralling cost of red meat, predators represent another threat to our economic structure by competing with consumers for this vital commodity.
\end{abstract}

Much has been written about differences in management objectives between "natural" and "managed" ecosystems. There are few, if any, natural ecosystems. Somewhere in the chain of "natural" events man has eliminated, weakened, or otherwise affected a link in the system by his very presence. Thus, all ecosystems are to a greater or lesser extent managed. To say that a balance of nature can be maintained in parks, wilderness areas, or elsewhere is grossly underestimating man's influence.

Most rangeland ecosystems evolved under the presence of native herbivores which subsequently were replaced by domestic animals. If grazing animals are required to maintain native rangelands in the semiarid West, and if the livestock enterprise is economically important to local, state, and national economies, then man must be permitted to manage predator species affecting those economies.

Predator management necessitates control of some predators in given areas and under certain sets of conditions. Wade (1974) noted that: "Nonlethal control of animals is not necessarily good, right or humane and lethal control is not necessarily bad, wrong or inhumane. These are human definitions and require subjective judgment." Individuals or groups genuinely interested in wildlife conservation must broaden their perspectives rather than advocate giving special advantage to predator species over other wild or domestic animals.

If predator management programs continue to be unsupported by the public and federal agencies, then the responsibility for controlling predators that directly affect the livelihood of private livestock operators, and indirectly local, state, and national economies, lies with federal and state wildlife biologists and game managers. These scientists must devise economic and biologically safe predator management methods. A combination of state and federal efforts on a local level where the problem is most critical would seem to be the solution to a perplexing problem.

\section{Literature Cited}

Arrington, O. N., and A. E. Edwards. 1951. Predator control as a factor in antelope management. Trans. No. Amer. Wildl. Conf. $16: 179-190$.

Atzert, Stephen P. 1971. A review of sodium monofluoroacetate (compound 1080)-its propertics, toxicology, and use in predator and rodent control. Bur. of Sport Fish. \& Wildl., Div. of Wildl. Serv., U.S. Dep. of the Interior, Washington, D.C. 36 p. (mimeo.).
Bright, Larry R. 1971. A survey of pertinent literature pertaining to predator interactions with big game. Predator-Prey Relationships Symposium, sponsored by Oregon Chapter, The Wildl. Soc., Corvallis, Ore. 15 p. (mimeo.).

Bruns, Eldon H. 1970. Winter predation of golden eagles and coyotes on pronghorn antelopes. Canadian Field Naturalist. 84:301-304.

Busner, Paul. 1972. Open letter to Wyoming sheepmen. Wyo. Wool Grower. 45(5):17.

Cadieux, Charles L. 1960. Culling the killers. Texas Game and Fish. 18(3):26-27,29.

Cain, Stanley A. (Chrmn.). 1972. Predator control-1971. Rep. to the Counc. on Environmental Quality and the Dep. of the Interior by the Advisory Committee on Predator Control. Univ. of Mich. Press, Ann Arbor. 207 p.

Carter, Arthur V., and Carl G. Trautman. 1969. Effect of predator control upon pheasant nesting success. S. Dak. Dep. Game, Fish \& Parks. Pittman-Robinson Rep. 25 p.

Cook, R.S., Marshall White, D. O. Trainer, and W. C. Glazener. 1971. Mortality of young white-tailed deer fawns in south Texas. J. Wildl. Manage. 35:47-56.

Davenport, John W., James E. Bowns, and John P. Workman. 1973. Assessment of sheep losses to coyotes-a problem to Utah sheepmen-a concern of Utah researchers. Utah State Univ., Agr. Exp. Sta. Res. Rep. 7. 17 p.

Extension Service. 1973. Western livestock round-up (Feb. 1973). Coop. Ext. Serv., So. Dakota State Univ. \& U.S. Dep. Agr. cooperating. So. Dakota State Univ., Brookings. 8 p.

Extension Service. 1974. Western livestock round-up (Feb. 1974). Coop. Ext. Serv., So. Dakota State Univ. \& U.S. Dep. Agr. cooperating. So. Dakota State Univ., Brookings. 8 p.

Gabrielson, Ira N. 1941. Wildlife conservation. The Macnillan Co., New York. 250 p.

Leopold, Aldo. 1948. Game management. Chas. Scribner's Sons, New York \& London. 481 p.

Leopold, A. Starker. 1964. Predator and rodent control in the United States. Trans. No. Amer. Wildl. Conf. 29:27-49.

Lorang, Glenn. 1974a. Today. Farm Journal, Inc., Philadelphia, Pa. Farm J. 98(6):31.

Lorang, Glenn. 1974b. Today. Farm Journal, Inc., Philadelphia, Pa. Farm J. 98(8):33.

Olsen, Jack. 1971. The poisoning of the West. The Reader's Digest. 99(592):69-74.

Pfohman, Bob. 1970. The Basque shecpherders. Democrat-Herald, Baker, Ore. Oct. 3, 1970. Reprinted in: "Press Clippings," Range Manage. Div., Forest Serv., U.S. Dep. Agr., Washington, D.C. Aug. 1971. $10 \mathrm{p}$.

Presnall, C. C. 1950 . The predator question-facts versus fancies. Trans. N. Amer. Wildl. Conf. 15:197-207.

Public Land Law Review Commission. 1970. One third of the nation's land. A report to the President and to the Congress. Supt. of Documents, U.S. Gov't. Printing Off., Washington, D.C. 342 p.

Robinson, W. B. 1961. Population changes of carnivores in some coyote-control areas. J. Mammal. 42:510-515.

Shelton, Maurice. 1973. Some myths concerning the coyote as a livestock predator. Bio. Science. 23(12):719-720.

Udy, Jay R. 1953. Effects of predator control on antelope populations. Utah State Dep. of Fish \& Game. Pub. No. 5.48 p.

U.S. Department of Agriculture. 1972. Agricultural statistics. Supt. of Documents, U.S. Gov't. Printing Off., Washington, D.C. 759 p.

U.S. Department of the Interior. 1972. Draft environmental statement on H.R. 13152. U.S. Dep. Interior, Washington, D.C.

Visher, Stephen S. 1914. A preliminary report on the biology of Harding County, northwestern South Dakota. S.D. Geological Survey Bull. No. 6. 103 p.

Vivion, Vern. 1972. Statement before the Environment Subcommittee, Senate Commerce Committee on S. 3334 and H.R. 13152. August 8, 1972. $18 \mathrm{p}$.

Wade, Dale A. 1974. The muddled matter of predator control. Colorado Outdoors. 23(1):5-10.

Woolfolk, E.J. 1949. Stocking Northern Great Plains sheep range for sustained high production. U.S. Dep. Agr., Circ. 804. 39 p. 